\title{
The Rights of Students in Courses Using Animals
}

\author{
Karen Davis \\ Potomac, Maryland
}

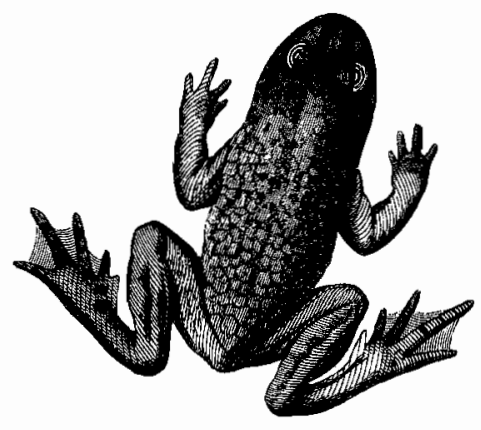

Should students have the right to exercise their ethical beliefs concerning animals by refusing to participate in class demonstrations or experiments that use animals? Should teachers be required to add an optional procedure for those students? In the past decade, two major trends in our society suggest that the answer to both questions is, or will ultimately be, yes.

From a moral perspective the view that nonhuman animals are fellow creatures entitled to moral concern as such is replacing the traditional outlook that sees them as mere resources for us to use however we choose. This changing outlook reflects the intellectual adjustment that is taking place in the realm of ideas, in keeping with the Darwinian perception that animals are our evolutionary kin. Moral consideration is increasingly being extended to all living things, and students are asserting their right not to harm animals in the classroom.

From a legal perspective, recent state and court actions have upheld the protection of students' right not to be forced to violate their ethical, spiritual, or religious beliefs in pursuit of their education, At the secondary level, the dissection of living animals was banned in Florida high schools, and students may be

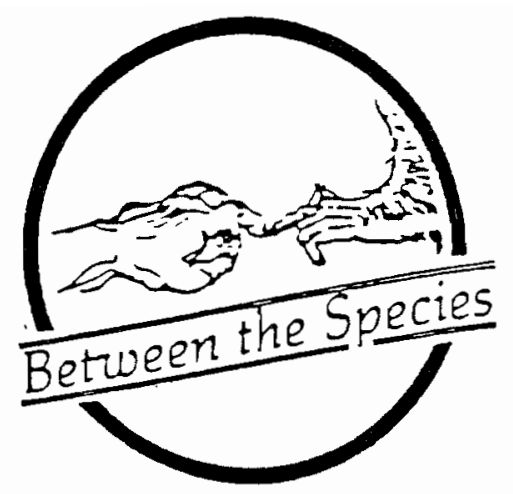

excused from dissecting a dead animal with a note from parents.

In California, students in grades kindergarten through high school have won the right to refuse to dissect, kill, or otherwise harm animals and to substitute an alternative activity. The 1993 Edition of the California Education Code on Pupils' Rights to Refrain from the Harmful or Destructive Use of Animals states that "If the pupil chooses to refrain from participation in an education project involving the harmful or destructive use of animals, and if the teacher believes that an adequate alternative education project is possible, then the teacher may work with the pupil to develop and agree upon an alternate education project for the purpose of providing the pupil an alternate avenue for obtaining the knowledge, information, or experience required by the course of study in question." The Code stipulates that the alternate education project may not be covertly used to punish the pupil by being more arduous than the original, animal-based, one. In addition, the pupil may choose an alternative testing procedure for course credit if the standard test requires the harmful or destructive use of animals.

In Maine, in 1989, the State Counselor of Education issued a Policy Advisory suggesting that students be informed that they may choose not to dissect but do an alternative project instead. Legislation pending in New Jersey, affecting high school students, provided a model

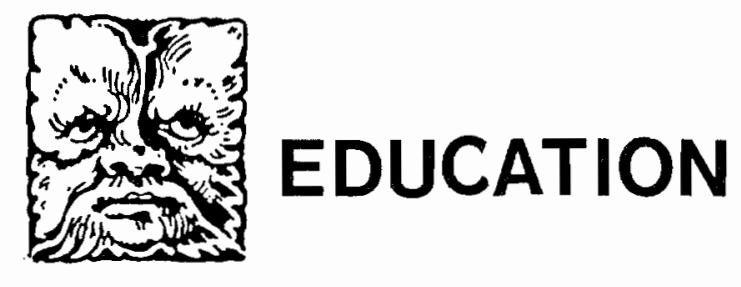


for the Maryland Senate bill that was introduced in 1990 in the Senate Economic and Environmental Affairs Committee. Despite strong testimony from scientists like Dr. F. Barbara Orlans, a research physiologist on the faculty of the Kennedy Institute of Ethics at Georgetown University, and from students, parents, and others who spoke before the Committee in favor of the bill, it was defeated, mainly as a result of opposition by the Maryland State Teachers Association. At the college level, students who took legal action at the University of Pennsylvania and the State University of New York won the right in out-of-court settlements to do a substitute procedure without penalty.

Recalling the controversy over conscientious objection at the time of the Viet Nam war, and similar cases based on the First Amendment right of free exercise of religion, the court has said that a moral conviction may occupy the same status as a religious belief, that is, be an all-encompassing principle that governs our actions and is entitled to court protection. In test cases, attorneys like Gary Francione and Anna Charlton of the Rutgers Animal Rights Law Clinic and those of the Animal Legal Defense Fund will argue that a student's right not to harm animals in the classroom arises from the First Amendment, state constitutional protection, civil rights laws, and in some cases, from contract and tort law principles. Gary Francione and Anna Charlton explain in the Introduction to their book Vivisection and Dissection in the Classroom: A Guide to Conscientious Objection (1992) that "As long as the student's objection can be phrased so that it falls under the first amendment to the Bill of Rights of our federal Constitution, then our legal system should offer protection to the student even if the system does not yet afford rights to animals" (ix).

Teachers' concern that accepting this student right would sanction a student's refusal, say, to read the Communist Manifesto or J. D. Salinger is met by the distinction that is made between thought and action, between academic knowledge (thinking, writing, discussing) and academic participation (performing or observing an action). Francione and Charlton state that "When a student is required to vivisect or dissect a nonhuman animal, the student is not merely being exposed to ideas with which she may disagree; rather, she is being asked to engage in an act that violates her religious freedom" (34).

The distinction between thought (ideas) and action (participation) is already incorporated into our legal system. For example, no one who conscientiously objects to performing abortions is forced to do so in medical school. Human fetal experiments are illegal in the classroom, for the law says that we cannot make people engage in what they conceive to be morally impermissible activities. As teachers, we can require students to read and talk about Communism, or cat anatomy, but can we equally force them to take part in an experimental commune or vivisect a cat? Does it not appear that the right of a student to refuse on moral grounds to injure or kill an animal supersedes the right of a teacher to refuse merely to add an option? This is the issue. The teacher is required to add a supplemental exercise for some students.

Meeting this requirement becomes easier each year, as students' growing demand for humane alternatives in the classroom is matched by innovative technology and textbooks reflecting society's changing outlook and needs. New guidebooks such as Alternatives in Biology Education published by the Biology Methods Review Project, Alternatives in Medical Education published by the Physicians Committee for Responsible Medicine, and Objecting to Dissection: A College Students' Handbook published by the Animal Legal Defense Fund demonstrate a range of non-animal teaching methods including computer programs, books, slides, videotapes and discs, filmstrips, charts, review sheets, transparencies, and cell biology programs. The trend among students is generating creative enterprise in research and development. A sign of the times can be seen in the editorial by Robert Cassidy in the January 1990 issue of $R \& D$ Magazine. Sharing the consensus of the magazine's October 1989 subscribers' opinion poll, he says, "I believe that making it mandatory for students to dissect animals against their will is a violation of their civil rights."

The question of whether the civil rights of students are being violated arose at the University of Maryland College Park Campus in Spring 1990. In May that year, the Campus Senate approved a "Policy on Participation by Students in Class Exercises that Involve Animals." The Policy asserts the responsibility of students to learn whether animals will be used in a course and the right of instructors to determine whether the use of animals will be optional or required. Departments with courses using animals must actively inform students of such courses.

A substitute policy would have required instructors to provide alternative activities at students' request. 
Those persons, including some students, who spoke on behalf of the substitute policy urged that this approach be viewed as a timely challenge in the best tradition of American higher education. In this tradition, students are allowed to benefit from the better and newer teaching models and techniques at their disposal. They are thus encouraged to learn well, and at the same time, to develop fully into the human, civilized beings which they have it in them to be.

\section{References}

Francione, Gary L. and Anna E. Charlton. Vivisection and Dissection in the Classroom: A Guide to Conscientious Objection. (Jenkintown, PA: The American AntiVivisection Society, 1992).

"Senate Debate on Rights and Responsibilities of Students in Courses Using Animals." The Faculty Voice. University of Maryland at College Park, Spring 1990.

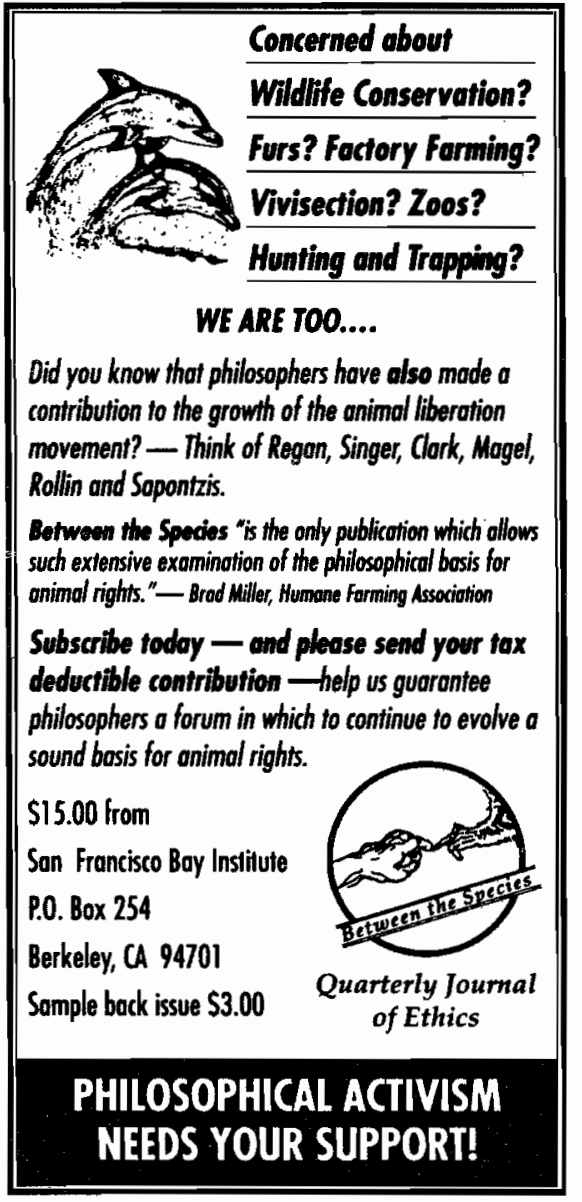

Bill, Why Do You Stare

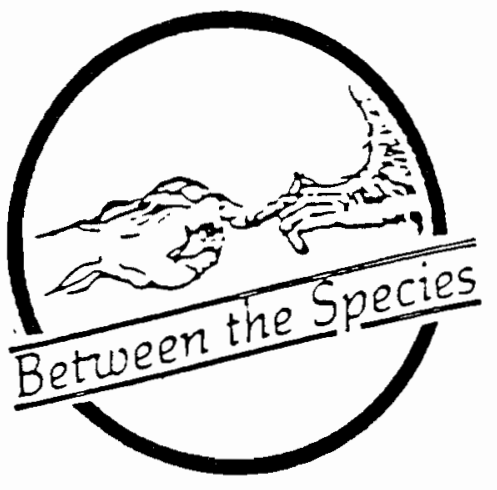

\section{at That Dog as if He Could Tell You Something?}

\section{Bill Kaul \\ University of Mississippi}

However you look at these animals,

even if the animal is up against the bars,

less than a foot from you,

looking outwards. in the public direction,

you are looking at something that has been rendered absolutely marginal;

and all the concentration you can muster will never be enough to centralise it.

Why is this?

Looking, John Berger, p.22

Consider.

I look at my dog, and I see that he is looking at me.

There is a space of air across which we are looking at each other.

I cannot know what is being seen by him as he looks at me.

What he sees, whether he thinks about the sights, if he is reifying the abstraction of "human" and feeling himself as subject, or if the picture he sees is just so many retinal impulses being coordinated, I cannot know.

He cannot say.

I know that I am looking at him, and I am aware of thought.

But I do not know where that thought is coming from. 